Archives of Agriculture and Environmental Science

\title{
Engineering provitamin A synthesis pathway with $\beta$-carotene metabolism in rice endosperm of a restorer line BR827R
}

\author{
S. Rehana ${ }^{1^{*}}$ (D) , N. Baishakh ${ }^{2}$, K. Datta ${ }^{3}$, N. Oliva ${ }^{4}$, E. Abrigo ${ }^{4}$, M.A. Mazid ${ }^{5}$, Shah-E-Alam ${ }^{6}$, M.R. \\ Uddin $^{7}$ and Swapan K. Datta ${ }^{8}$
}

${ }^{1}$ Bio-Technology and Genetic Engineering Discipline, Khulna University, Khulna 9208, BANGLADESH

${ }^{2}$ School of Plant Environmental and Soil Sciences, Lousiana State University, 214 M.B. Sturgis Hall Baton Rouge, LA 70803, USA

${ }^{3}$ Laboratory of Translational Research on Transgenic Crops, Department of Botany, University of Calcutta, Kolkata-700073

(West Bengal), INDIA

${ }^{4}$ Plant Tissue Culture Laboratory, International Rice Research Institute, DAPO 7777, Metro Manilla, PHILIPPINES

5 525/A, Senpara Parbata, Mirpur 14, Dhaka 1216, BANGLADESH

${ }^{6}$ Department of Genetics and Plant Breeding, Bangladesh Agricultural University, Mymensingh 2202, BANGLADESH

7 Department of Agronomy, Bangladesh Agricultural University, Mymensingh 2202, BANGLADESH

${ }^{8}$ Department of Crop Science, Institute of Agriculture, Visva Bharati University, Santiniketan- 731235 (West Bengal), INDIA

*Corresponding author's E-mail: saydarehana@gmail.com

\section{ARTICLE HISTORY}

Received: 28 April 2018

Revised received: 10 May 2018

Accepted: 15 May 2018

\section{Keywords}

$\beta$-carotene

Biolistic transformation

Provitamin A

Restorer line

\section{ABSTRACT}

Vitamin A deficiency (VAD) is a serious public health problem in South Asia particularly in Bangladesh. Indica rice as a major staple in the country completely lacks vitamin A or compounds with provitamin A activity after milling. A combination of transgenes has been introduced enabling biosynthesis of provitamin $A$ in the endosperm of a restorer line using biolistic system of transformation. The rice seed-specific glutelin promoter (Gt-1 P) was used to drive the expression of phytone synthase (psy), while lycopene b-cyclase (Icy) and phytoenedesaturase (crtl), fused to the transit peptide sequence of the pea-Rubisco small subunit, were driven by the constitutive cauliflower mosaic virus promoter (CaMV35s P). Transgenic plants were recovered through selection with CaMV35sP driven hph (hygromycinphosphotransferase) gene. Molecular analysis demonstrated stable integration and expression of the transgenes. The variable segregation pattern in $\mathrm{T}_{1}$ generation indicated single to multiple insertions of the transgenes in the genome. This is the first report of the development of a transgenic restorer line with carotenogenic pathway into the endosperm for use of hybrid rice improvement.

(C)2018 Agriculture and Environmental Science Academy

Citation of this article: Rehana, S., Baishakh, N., Datta, K., Oliva, N., Abrigo, E., Mazid, M.A., Shah-E-Alam, Uddin, M.R. and Datta, S.K. (2018). Engineering provitamin A synthesis pathway with $\beta$-carotene metabolism in rice endosperm of a restorer line BR827R. Archives of Agriculture and Environmental Science, 3(2): 103-108, https://dx.doi.org/10.26832/24566632.2018.030201

\section{INTRODUCTION}

Vitamin A is an essential vitamin for mammals. Mammals are not able to produce carotenoids because of the complete absence of the biosynthetic pathway beginning with the synthesis of phytoene from GGPP. Dietary $\beta$-carotene therefore serves as an important precursor for the synthesis of vitamin A. Most dietary vitamin $A$ is derived from plant food in the form of provitamin $A$, the carotenoids, which are converted to vitamin $A$ in the body (Sivakumar, 1998). Dietary $\beta$-carotene is converted into vitamin $A$, also known as retinol, by oxidative cleavage of the central double bond followed by a reduction of the terminal aldehyde.

Vitamin A plays role in the normal development of humans (Bendich, 1993, 1994; West et al., 1989) and in other mammals. Furthermore, recent investigations have reported that vitamin A quenches free radicals and prevents cellular oxidative damage, as well as supporting the human immune system (Bendich, 1989, 1993; Ross, 1992). In mammals $\beta$-carotene and some structurally related compounds have provitamin A character. Carotenoids, present in all photosynthetic and many non-photosynthetic organisms are a widely distributed class of 
natural pigments containing 40 carbon arms. Carotenoid biosynthesis represents one intracellularly specialized branch of general isoprenoid metabolism in plants. Whereas sesqui- and triterpenoids are produced in the cytoplasm, mono-, di- and tetraterpinoids are synthesized in plastids (Kleinig, 1989). These pigments are well known as essential components of the photosynthetic apparatus. Carotenoids are also produced in the chloroplast of flowers and fruits, where they serve as visual attractants of insects and animals to facilitate pollination and seed dispersal. In some cases, such as maize and potato, carotenoids also can be formed in the amyloplasts of plant storage tissues.

It has been established that four enzymes in plants, i.e. phytone synthase, phytone desaturase, $\zeta$-carotene desaturase, and lycopene cyclase to complete the pathway toward $\beta$-carotene (provitmain A) biosynthesis from GGPP (for review see Britton, 1988; Cunningham and Grantt, 1998; Sandmann, 1994, 2001). The first step in carotenoid biosynthesis is the condensation of two molecules of GGPP to produce phytone by the enzyme phytone synthese (PSY). PSY is firmly associated with the chromoplast membrane in its active form (Schledz et al., 1996). Comparing to plants, anoxygenic photosynthetic bacteria, non-photosynthetic bacteria and carotenoid-synthesizing fungi do not possess a distinct phytone desaturase (PDS) and $\zeta$ carotene desaturase (ZDS) to catalyse the conversion of phytone to lycopene. In non-photosynthetic-bacteria, phytone is converted to all-trans lycopene by a single enzyme phytone desaturase (CRTI). In order to cyclaze of lycopene two different lycopene cyclase specific $\alpha$ - and $\varepsilon$-ionone end-groups of LCY marks a branching point in the pathway where one branch leads to $\alpha$-carotene and its oxygenated derived lutein, while the other forms $\beta$-carotene and the derived xanthophylls, such as zeaxanthin, antheraxanthin, violaxanthin and neoxanthin (for review see Hirschberg, 2001). The genes necessary for these enzymes have been isolated and their function elucidated from a variety of fungi, bacteria and plants (Al-Babili et al., 1999; Armstrong et al., 1990; Misawa et al., 1993; Buckner et al., 1993; Hundle et al., 1991; Misawa et al., 1990; Scolnik and Bartley, 1994, 1996; To et al., 1994).

Conventional interventions (supplementation, fortification, food based diversification etc) have been helpful in defeating VAD but were not sufficiently effective. Plant breeding to alter, modify or introduce this biosynthetic machinery into the target tissues in rice has been impossible as of now, as no endosperm active carotenoid-biosynthetic genes have found thus far in the available rice gene pool (Tan et al., 2005). Therefore recombinant DNA technology and plant biotechnology, with abovementioned molecular tools in hand, represents an alternative method to combat VAD. Moreover it may represent a sustainable strategy (Zimmerman and Hurrel, 2002).

Golden Rice as published (Ye et al., 2000) demonstrates the feasibility of the scientific approach but does not yet represent a product. The carotenogenic pathway introduced earlier in the endosperm of various indica rice cultivars well established in different developing countries (Datta et al., 2003) cannot be used directly for developing provitamin A enriched hybrids. Therefore, this study was undertaken to develop a provitamin A enriched restorer $(r)$ line which will directly help to produce carotenoid enriched hybrid rice. Through biolistic method of gene transformation Phytone synthase (psy), bacterial phytone desaturase (crtl), and lycopene cyclase (lcy) genes were introduced into the endosperm of a restorer line to derive the accumulation of $\beta$-carotene. This is the initial report to develop a transgenic $\beta$-carotenoid restorer line, a new tool for improving hybrid rice.

\section{MATERIALS AND METHODS}

Selection of genotype and plasmid for transformation experiments

An elite indica restorer line (BR827R) was selected for transformation on the basis of its superior grain quality. Altogether three different plasmids were used for the co-transformation experiments. The vector pBall3 (Figure 2) contained the daffodil phytone synthase (psy) gene (Burkhardt et al., 1997) under control of an endosperm-specific Gt1 promoter and a bacterial phytone desaturae (crtl) gene fused to a transit peptide sequence of a pea-rubisco small subunit (Misawa et al., 1993) to direct the expression of this bacterial gene into the plastids by constitutive $35 \mathrm{~S}$ promoter. In order to yield the plasmid pTCL6 (Figure 2) under control of the 35S promoter and nopaline synthase terminator, lycopene $\beta$-cyclase (Icy) cDNA (Al-Babili et al., 1999) was subcloned from pCyBlue with the Kpnl-BamHI site of pGL2 (Gritz and Davies, 1983); to the selectable marker gene, plasmid pGL2 (Figure 2) containing the selectable marker gene hph for hygromycinphosphotransferase under CaMV 35S promoter (Datta et al., 1990).

Experimental design for transformation experiments

Rice immature embryos were used as target explants for cotransformation (Figure 3) of the above-mentioned vectors using the PDS-1000He particle gun. Selection started 16-20 hours after bombardment on fresh callus induction medium containing 40-mg/L hygromycin as described earlier (Figure 3) (Datta et al., 1998). The putative primary transgenics and the subsequent seed progenies were grown in the containment greenhouse of IRRI, following a day night temperature regime of $29 / 22 \pm 2{ }^{\circ} \mathrm{C}$ and $70-85 \%$ relative humidity. A stepwise methodology of rice transformation experiment has been given in figure 1 .

Polymerase chain reaction (PCR) and southern blot analysis

Genomic DNA was isolated from 1-month-old plants using the micro prep method and 50-100 ng of template DNA was used for PCR analysis with gene-specific primers (Table 1) as described earlier (Baisakh et al., 2001). Plant genomic DNA was extracted from the freshly harvested leaves of transgenic and non-transgenic control plants for southern analysis, following the modified CTAB method (Murray and Thomson, 1980). Ten micrograms of DNA were digested overnight with EcoRI-HindIII 
for psy and Icy, BamHI for crtl and run in 1\% TAE-agarose gel. Southern membrane transfer, hybridization and exposure were done as previously described (Datta et al., 1998). PCR-amplified fragments of the three genes were radiolabelled with $\left(\alpha-{ }^{32} P\right)-$ dCTP and used as hybridization probes.

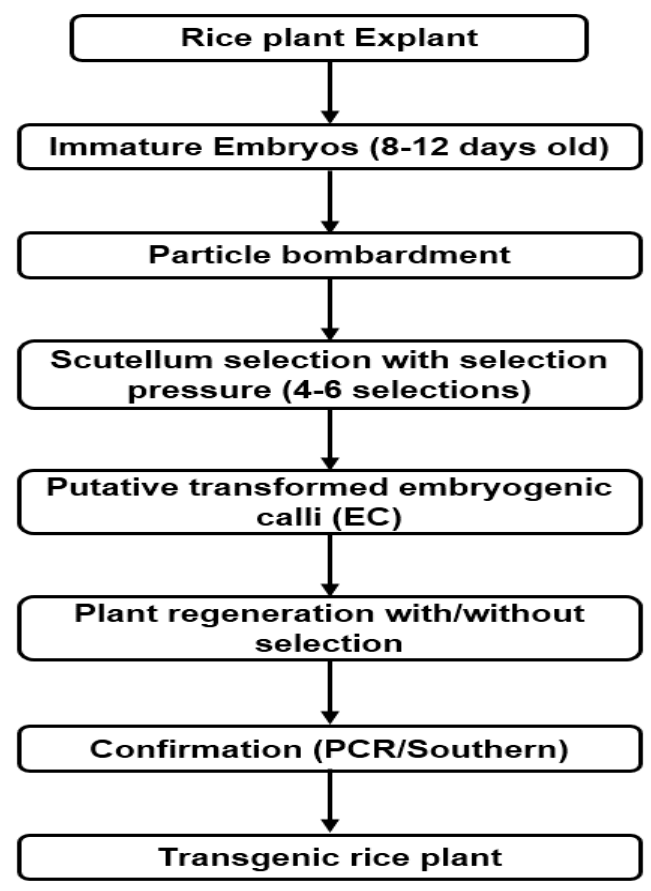

Figure 1. Stepwise rice transformation experiment.
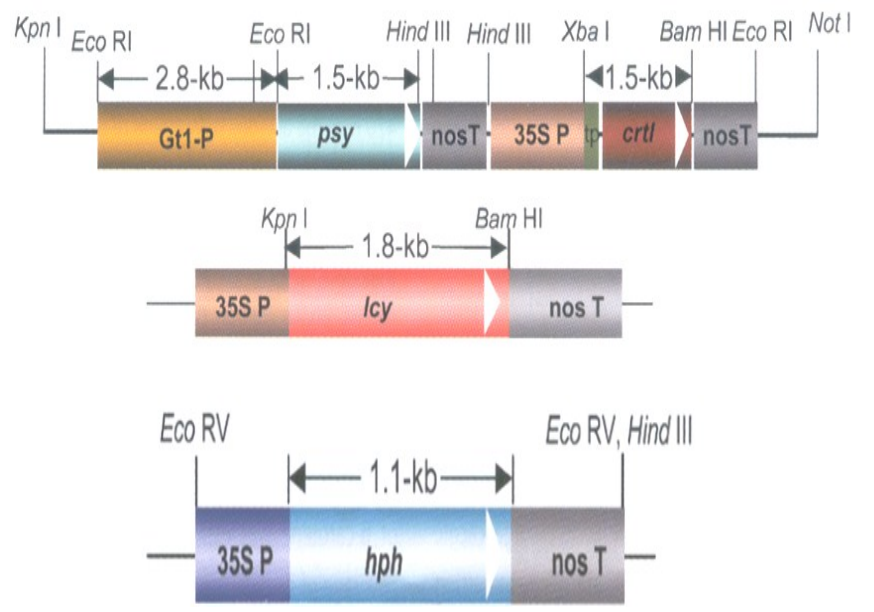

Figure 2. Partial map of the plasmids: a. pBaal3 containing psy and crtl, b. pTCL6 containing lcy and c. pGL2 with hph.

\section{RESULTS AND DISCUSSION}

\section{Assessment of $\mathrm{T}_{0}$ transformants}

Out of the eight independent bombardments (600 IE each) of BR827R, a small number of $T_{0}$ transgenic plants (46) produced, three independently transformed lines SBR827R7, SBR827R11 and SB827R12 were recovered and presented in the study. The insertion of the genes in the genome was primarily checked by PCR analysis (Figure 4) and then confirmed by southern blot analysis (Figure 5). The $1.5 \mathrm{~kb}$ and $1.6 \mathrm{~kb}$ size bands confirmed the integration of psy and crtl gene respectively (Figure 5). When the blot was hybridized with $1.5 \mathrm{~kb}$ psy probe the three lines showed expected size band (Figure 5). In case of crtl gene, hybridization occurred in the high molecular weight regions in lane 1 (Figure 5) containing not expected size DNA of crtl gene, suggesting rearrangement of the transgene. Two of them contained a fragment of the expected size that suggests a correct and intact integration of the crtl cDNA (Figure 5). Peter Burkhardt (1996) also reported while the plants were co transformed with plasmids $\mathrm{pCPsyH}$ and $\mathrm{pCPdsH}$, both higher and expected size was observed. However, two transformants were fertile and one line SBR827R12 was sterile. Between the two fertile lines SB827R7 produced sufficient seeds and the other line SB827R11 produced very few seeds.

\section{Evaluation of $\mathrm{T}_{1}$ progeny}

B-carotenoid positive $T_{1}$ progeny from both transformants were identified by southern blot analysis. Results of southern blot analysis of the progeny from both transformants are shown in Figure 5. In the progeny lines of SBR827R-7 showed (Figure 6) same integration pattern of $1.5-\mathrm{kb}$ size psy gene like $\mathrm{T}_{0}$ line and genomic DNA was digested with EcoR1/HinDIII restriction enzyme. Out of 14 progeny lines of SBR827R-7, 9 lines were positive with expected size psy DNA. When the same blot was reprobed with crtl gene (PCR originated) all the psy positive lines showed integration of crtl gene in the genome (Figure 4). The banding pattern in $T_{1}$ was same as previously shown in $T_{0}$ (Figure 5) not expected size in all SBR827R-7 progeny lines. In case of SBR827R-11, two lines were positive but one showed rearranged banding pattern (Figure 4). In $T_{0}$, SBR827R-11 gave expected size $1.6 \mathrm{~kb}$ sized $\mathrm{crtl}$ (Figure 5), but in case of $\mathrm{T}_{1}$ some rearrangement may be occurred. Between two positive lines one showed expected size SBR827R11-4, 1.6-kb crtl but

Table 1. General features of selected plasmids for transformation experiments.

\begin{tabular}{|c|c|c|c|c|}
\hline Plasmid & $\begin{array}{c}\text { Target gene (s)/ } \\
\text { sequence (s) }\end{array}$ & Primer sequences & Specific features & Source \\
\hline pBaal3 & Psy and Crt 1 & $\begin{array}{l}\text { PsyF: TGGTGGTTGCGATATTACGA, } \\
\text { psy R: ACCTTCCCAGTGAACACGTC } \\
\text { Crtl F: GGTCGGGCTTATGTCTACGA, } \\
\text { crtI R: ATACGGTCGCGCGTAGTTTTGG }\end{array}$ & $\begin{array}{l}\text { Phytoene synthase } \\
\text { and Carotene } \\
\text { desaturase }\end{array}$ & $\begin{array}{l}\text { Datta et al. } \\
\text { (2003) }\end{array}$ \\
\hline pTCL6 & Lcy & $\begin{array}{l}\text { Lcy F: CCAATCCCCAGAACCCTAAT, } \\
\text { Icy R: CTCGCTACCATGTAACCCGT }\end{array}$ & Lycopene cyclase & \\
\hline pGL2 & hph & & $\begin{array}{l}\text { Selectable marker } \\
\text { gene }\end{array}$ & $\begin{array}{c}\text { Datta et al. } \\
(1990)\end{array}$ \\
\hline
\end{tabular}


SBR827R11-2 showed comparatively upper band means high molecular weight of the transgene (Figure 6). The different banding pattern in SB827R11 indicates that a rearrangement of the transgene may occur in successive generations. This may be due to deletion, addition or translocation of the transgene. However, further study on this aspect is needed. Multiple

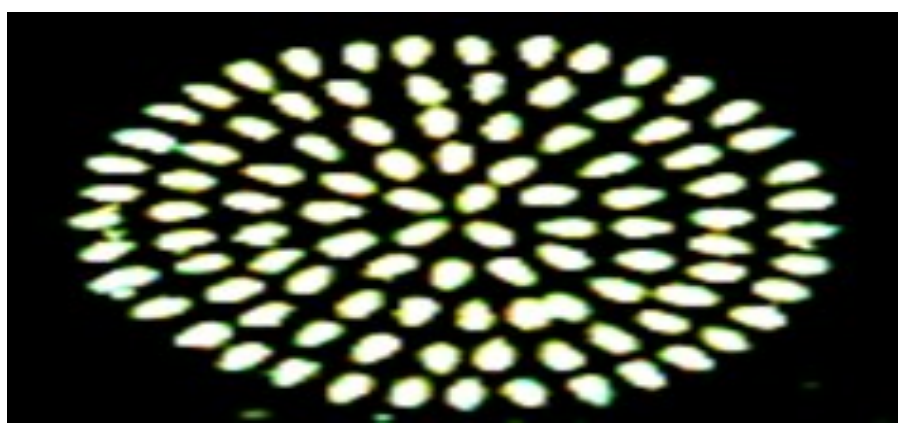

a

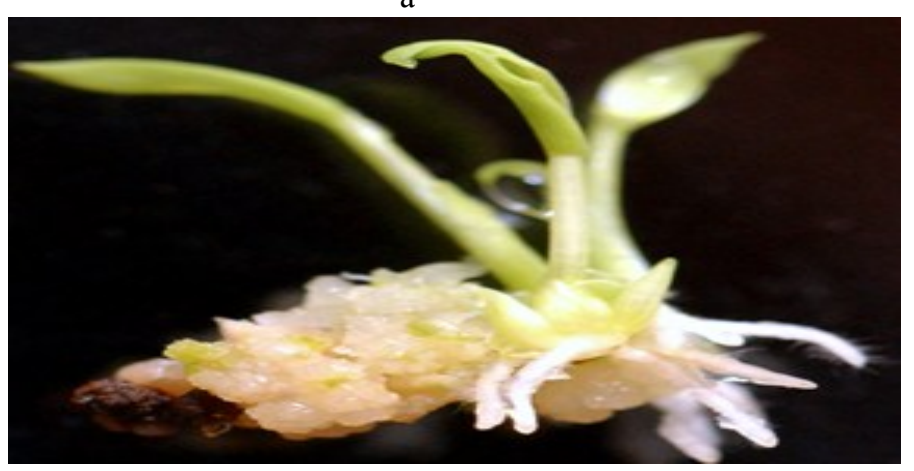

c

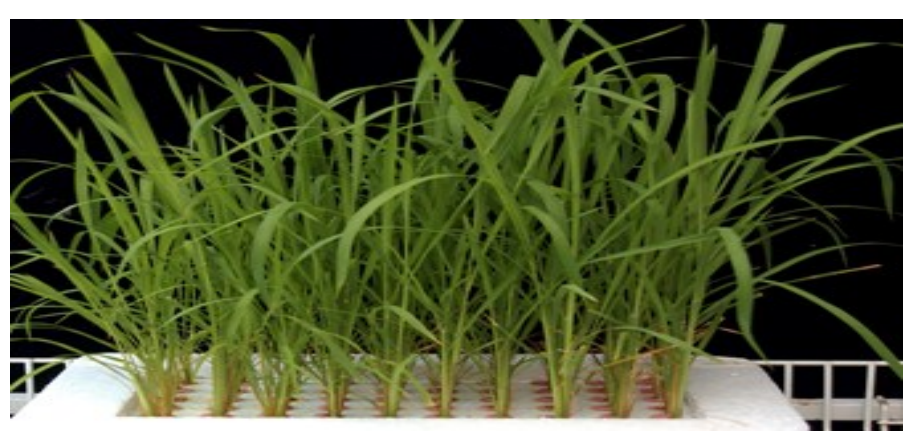

e

Figure 3. Generation of transgenic rice plant by particle bombardment mediated transformation; $a$. circular arrangement of IE; $b$. Resistant calli in selection medium; c. Regenerated plantlet; $d$. Plantlet in rooting medium; $e$. In yoshida's solution. generations and additional progeny analysis may provide useful information regarding such rearrangements. Goto et al. (1993) showed differences in banding patterns among $\mathrm{T}_{2}$ progenies of transgenic rice plants. Nayak et al. (1997) also reported different southern patterns among progenies of specific transformation event they analyzed.

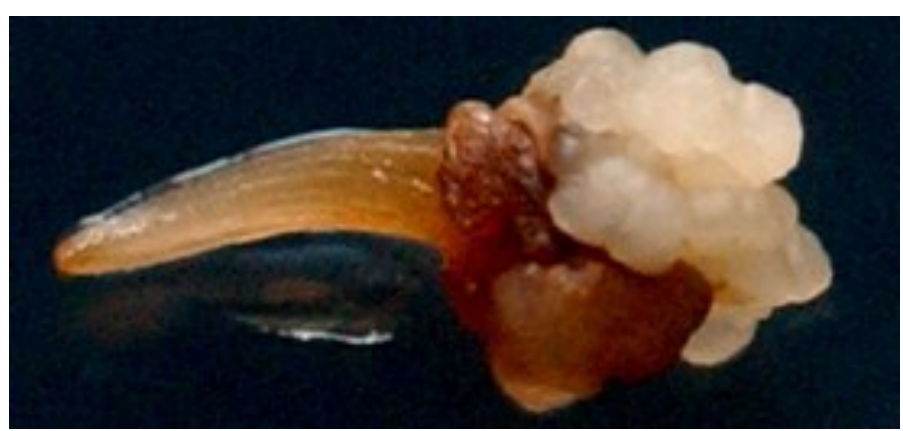

b

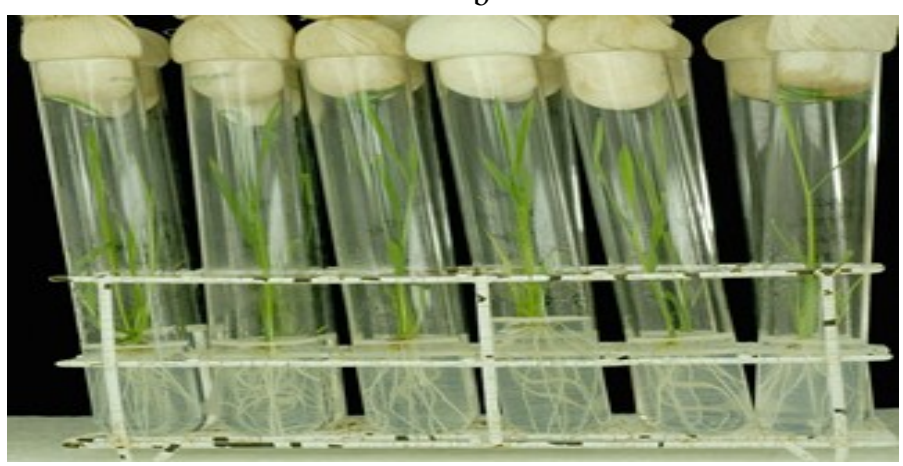

d

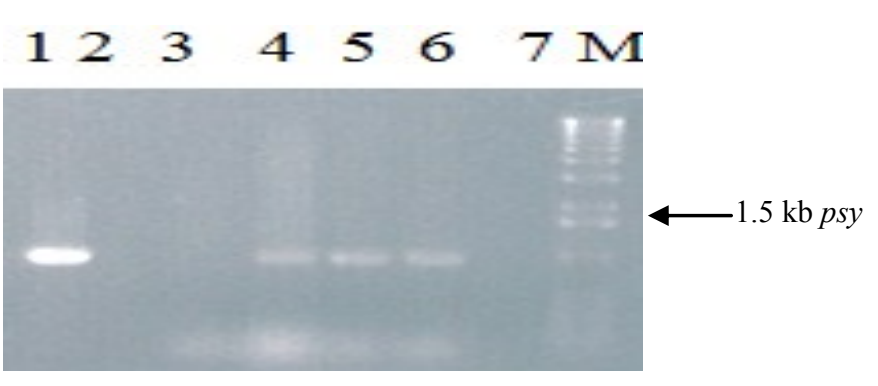

Figure 4. PCR analysis showing amplification of $1.5 \mathrm{~kb}$ size band of psy gene in the primary transgenics. Lane 1, plasmid control; lane 2, blank; lane 3, non-transformed control plant; lane 4, 5, 6 three individual transformants; lane 7, blank; and M, 1 kb DNA molecular marker.

\section{2 b 345 b 678 b 910 b NCb b PC}

$\begin{array}{llllllllllllllllllll}1 & 2 & 3 & 4 & 5 & 6 & 7 & 8 & b & 9 & b & 10 b & b & N C b & b & P C\end{array}$

a.

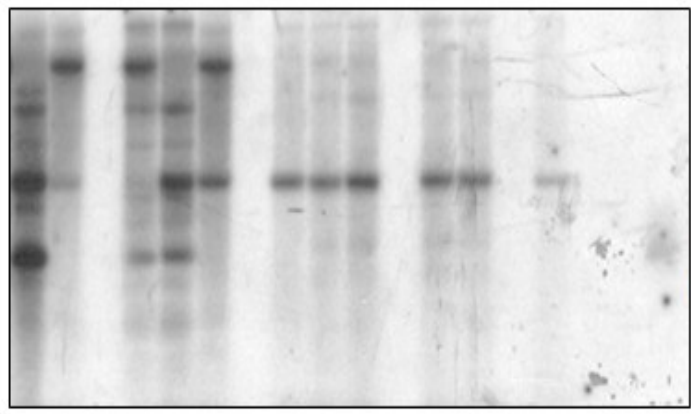

b.

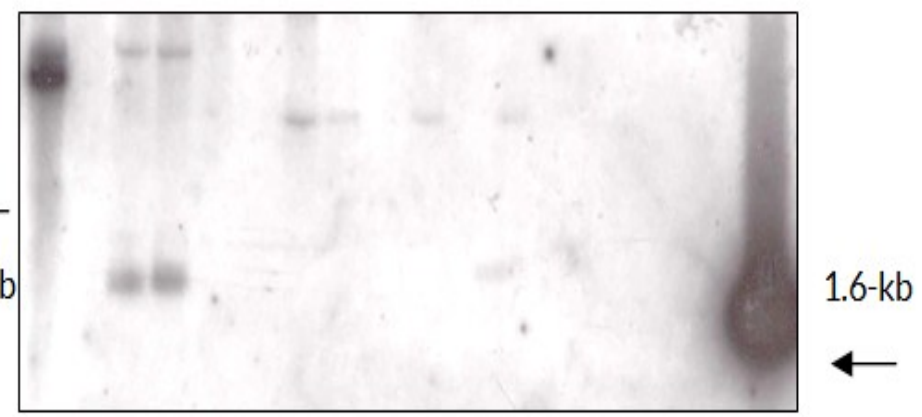

Figure 5. Southern blots showing the integration of a) psy, b) crtl in the primary transgenics of restorer line BR827R(EcoRI/HinDIII-digested PBaal3 forpsyand BamHI forcrtI). Ten $\mu \mathrm{g}$ of genomic DNA were digested overnight, electrophoresed in 1\% TAE-agarose gel, southern blotted and hybridized with (32p) dCTP-labelled probes ofpsy and crtl (PCR-generated). Lanes 1.SBRR7, 2.SBRR10, 3.SBRR11, 4. SBRR12, 5.SBRR13, 6.SBRR14, 7.SBRR15, 8. SBRR16, 9.SBRR17 and 10.SBRR18. b. blank, NC-negative control, PC-positive control. 
a.
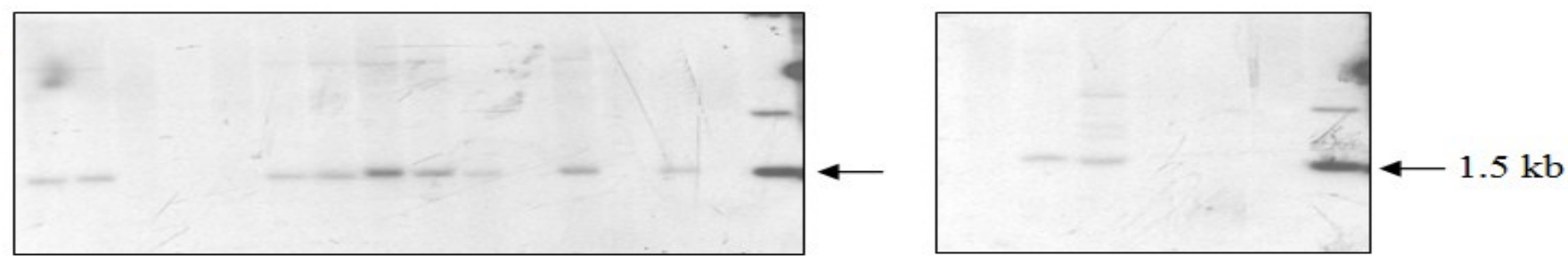

$\begin{array}{lllllllllllllllll}1 & 2 & 3 & 4 & 5 & 6 & 7 & 8 & 9 & 10 & 11 & 12 & 13 & 14 & \mathrm{C} & \mathrm{PC}\end{array}$

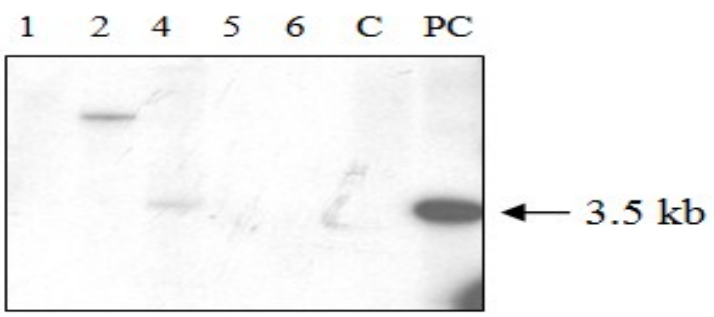

Figure 6. Southern blots showing the integration of a) psy,b) crtl in the $T_{1}$ progenies of SBRR7 and SBRR11 line. Ten $\mu g$ of genomic DNA was digested with EcoRI/HindIII for overnight, electrophorased in 1\% TAE-agarose gel, southern blotted and hybridized with (32p) dCTP-labeled probes of psy and crtl (PCR generated).

Conclusion

This investigation concluded that a restorer ( $r$ ) line BR827R for hybrid rice production was used to explore the potential for transformation of Indica rice adapted in Bangladesh. Rice immature embryos were transformed with pBaal3, pTCL6 and pGL2 using the particle gun transformation system. The transgenic plants were confirmed by PCR and Southern Blot analysis. Hybridization with psy, crtl, Icy and hph probes suggested the integration of the respective genes in the genome of the transgenic BR827R plants.

\section{ACKNOWLEDGEMENTS}

Financial support from USAID and the Rockefeller Foundation, as well as Plant Breeding, Genetics and Biotechnology laboratory, International Rice Research Institute (IRRI), Philippines are acknowledged.

Open Access: This is open access article distributed under the terms of the Creative Commons Attribution License, which permits unrestricted use, distribution, and reproduction in any medium, provided the original author(s) and the source are credited.

\section{REFERENCES}

Al-Babili, S., Hartung, W., Kleinig, H. and Beyer, P. (1999). CPTA Modulates Levels of Carotenogenic Proteins and their mRNAs and Affects Carotenoid and ABA Content as well as Chromoplast Structure in Narcissus pseudonarcissus Flowers. Plant Biology, 1(6): 607-612, https:// doi.org/10.1111/j.1438-8677.1999.tb00270.x

Armstrong, G.A., Schmidt, A., Sandmann, G. and Hearst, J.E. (1990). Gentic and biochemical characterization of carotenoid biosynthesis mutants of Rhodobacter capsulatus. Journal of Biological Chemistry, 265: 8329-8338, https:// pdfs.semanticscholar.orge312/00a27fa85d941fe21ff903a d6520766a3f4a.pdf_ga=2.66707366.90914088.15259487 24-977545506.1525948724

Baisakh, N., Datta, K., Rai, M., Rehana, S., Beyer, P., Potrykus, K and Datta, S.K. (2001). Development of dihaploid trasnsgenic "Golden rice" homozygous for genes involved in the metabolic pathway for beta-carotene biosynthesis. Rice Genetics Newsletter, 18: 91-94, https://shigen.nig.ac.jp/rice/ oryzabase/asset/rgn/vol18/c41.html

Bendich, A. (1989). Carotenoids and immune response. Journal of Nutrition, 119: 112-115, https://doi.org/10.1093/ jn/119.1.112

Bendich, A. (1993). Biological function of dietary carotenoids. Annals of New York Academy of Science, 691: 61-67, https:// doi.org/10.1111/j.1749-6632.1993.tb26157.x

Bendich, A. (1994). Recent advances in clinical research involving carotenoids. Pure and Applied Chemistry, 66: 287-301, https://doi.org/10.1351/pac199466051017

Britton, G. (1988). Biosynthesis of carotenoids. In Plant pigments, T.W. Goodwin, (ed.) (London: Academic press), pp. 133-182.

Buckner, B., San Miguel, P. and Bennetzen, J.L. (1993). The Y1 gene codes for phytone synthase. Maize Genetics Cooperation Newsletter, 678: 65, https://www.ncbi.nlm.nih.gov/pmc/ articles/PMC1207279/pdf/ge1431479.pdf

Burkhardt, P.K., Beyer, P., Wunn, J., Kloti, A., Armstrong, G.A., Scledz, M., von Lintig, J. and Potrykus, I. (1997). Transgenic rice (Oryza sativa) endosperm expressing daffodil (Narcissus pseudonarcissus) phytoene synthase accumulates phytoene, a key intermediate of provitamin A biosynthesis. The Plant Journal, 11(5): 1071-1078, https://onlinelibrary.wiley.com/ doi/pdf/10.1046/j.1365-313X.1997.11051071.x

Cunningham, F. X. J. and Gantt, E. (1998). Genes and enzymes of carotenoid biosynthesis in plants. Annual Review of Plant Physiology and Molecular Biology, 49: 577-583, https://doi.org/10.1146/ annurev.arplant.49.1.557

Datta, K., Baishakh, N., Oliva, N., Torrizo, L., Abrigo, E., Tan, J., Rai, M., Rehana, S., Al-Babili, S., Beyer, P., Potrykus, I. and Datta, S. K. (2003). Bioengineered "golden" indica rice cultivers 
with b-carotene metabolism in the endosperm with hygromycin and mannose selection system. Plant Biotechnology Journal, 1: 81-90, https://doi.org/10.1046/j.14677652.2003.00015.x

Datta, K., Vasquez, A., Tu, J., Torrizo, L., Alam, M.F., Oliva, N., Abrigo, E., Khush, G.S. and Datta, S.K. (1998). Constitutive and tissue-specific differential expression of $\operatorname{cry} 1 \mathrm{~A}(\mathrm{~b})$ gene in transgenic rice plants conferring enhanced resistance to insect pests. Theoretical and Applied Genetics, 97: 20-30, https://doi.org/10.1007/s001220050862

Datta, S. K., Peterhans, A., Datta, K. and Potrykus, I. (1990). Genetically engineered fertile indica-rice plants recovered from protoplasts. Nature Biotechnology, 8: 736-740, https:// doi.org/10.1038/nbt0890-736

Goto, F., Toki, S. and Uchimiya, H. (1993). Inheritance of a co-transferred foreign gene in the progenies of transgenic rice plants. Transgenic Research, 2: 300-305, https:// link.springer.com/article/10.1007/BF01968842

Gritz, L. and Davies, J. (1983). Plasmid-encoded hygromycin B resistance: the sequence of hygromycin $B$ phosphotranferase gene and its expression in Escherichia coli and Saccharomyces cerevisiae. Gene, 25: 179-188, https:// doi.org/10.1016/0378-1119(83)90223-8

Hirschberg, J. (2001). Carotenoid biosynthesis in flowering plants. Current Opinion in Plant Biology, 4: 210-218, https:// doi.org/10.1016/S1369-5266(00)00163-1

Hundle, B., Beyer, P., Kleinig, H., Englert, G. and Hearst, J.E. (1991). Crotenoids of Erwinia herbicola and Escherichia coli HB101 strain carrying the Erwinia herbicola carotenoid gene cluster. Photochemistry and Photobiology, 54(1): 89-93, https://doi.org/10.1111/j.1751-1097.1991.tb01989.x

Kleinig, H. (1989). The role of plastids in isoprenoid biosynthesis. Annual Review of Plant Physiology and Molecular Biology, 40: 39-59, https://doi.org/10.1146/ annurev.pp.40.060189.000351

Misawa, N., Nakagawa, M., Kobayashi, K., Y amano, S., Izawa, Y., Naka mura, K. and Harashima, K. (1990). Elucidation of the Erwinia uredovora carotenoid biosynthetic pathway by functional analysis of gene produces expresses in Escherichia coli. Journal of Bacteriology, 172: 6704-6712, https:// doi.org/10.1128/jb.172.12.6704-6712.1990

Misawa, N., Yamano, S., Linden, H., deFelipe, M.R., Lucas, M., Ikenaga, H. and Sandmann, G. (1993). Functional expression of the Erwinia uredovora carotenoid biosynthesis gene $\mathrm{crtl}$ in transgenic plants showing an increase of $\beta$-carotene biosynthesis activity and resistance to the bleaching herbicide norflurazon. The Plant Journal, 4(5): 833-840, https:// doi.org/10.1046/j.1365-313X.1993.04050833.x

Murray, M. G. and Thompson, W. F. (1980). Rapid isolation of high molecular weight plant DNA. Nucleic Acids Research, 8: 4321-4235, https://doi.org/10.1093/nar/8.19.4321

Nayak, P., Basu, D., DAS, S., Basu, A., Ghosh, D., Ramakrishna, N. A., Ghosh, M. and Sen, S.K. (1997). Transgenic elite indica rice plants expressing cry $1 \mathrm{~A}$ (C) $\delta$-Endotoxin of Bacillus thuringiensis are resistant against yellow stem borer
(Scirpophaga incertulas). Proceedings of the National Academy of Science (USA), 94: 2111-2116, https:// www.ncbi.nlm.nih.gov/pubmed/9122157

Ross, A.C. (1992). Vitamin A status: relationship to immunity and the antibody response. Proceedings of the Society for Experimental Biology and Medicine, 200 (3): 303-320, http:// journals.sagepub.com/doi/pdf/10.3181/00379727-20043436A

Sandmann, G. (1994). Carotenoid biosynthesis in microorganisms and plants. European Journal of Biochemistry, 223: 7-24, https://link.springer.com/chapter/10.1007/978-3-64279502-2_10

Sandmann, G. (2001). Carotenoid biosynthesis and biotechnological application. Archives of Biochemistry and Biophysics, 385 (1): 4-12, https://doi.org/10.1006/abbi.2000.2170

Schledz, M., Al-Babili, S., V onLintig, J., HaucKleinig, H. and Beyer, P. (1996). Phytoenesynthas from Narcissus pseudonarcissus: functional expression, galactolipid requirement, topological distribution in chromoplasts and induction during flowering. The Plant Journal, 10: 781- 792, https://doi.org/10.1046/ j.1365-313X.1996.10050781.x

Scolnik, P. A. and Bartley, G. E. (1994). Nucleotide sequence of an Arabidopsis cDNA for phytoene syntheses. Plant Physiology, 104: 1471-1472, http://www.plantphysiol.org/content/ plantphysiol/104/4/1471.full.pdf

Scolnik, P. A. and Bartley, G. E. (1996). Table of some cloned plant genes involved in isoprenoidbiosynthesis. Plant Molecular Biology Reporter, 14 (4): 305-319, http://dx.doi.org/10.1007/ BF02673363

Sivakumar, B. (1998). Current controversies in carotene nutrition. Indian Journal of Medical Research, 108: 157-166.

Tan, J., Baisakh, N., Oliva, N., Parkhi, V., Rai, M., Torrizo, L., Datta, K., Datta, S.K. (2005). The screening of rice germplasm, including those transgenic rice lines which accumulate betacarotene in their polished seeds, for their carotenoid profile. International Journal of Food Science and Technology, 40: 563569, https://doi.org/10.1111/j.1365-2621.2005.00971.x

To, K.Y., Lai, E.M., Lee, L.Y., Lin, T.P., Hung, C.H., Chen, C.L., Chang, Y.S. and Liu, S.T. (1994). Analysis of the gene cluster encoding carotenoid biosynthesis in Erwinia herbicola EHO13. Microbiology, 140: 331-339, https:// doi.org/10.1099/13500872-140-2-331

West, KP Jr., Howard, G.R. and Sommer, A. (1989). Vitamin A and infection: public health implications. Annual Review of Nutrition, 9: 63-86, https://doi.org/10.1146/annurev. nu.09.070189.000431

Ye, Xu., Al-Babili, S., Kloti, A., Zhang, J., Lucca, P., Beyer, P. and Potrykus, I. (2000). Engineering the provitamin A (Betacarotene) biosynthetic pathway into (carotenoid - free) rice endosperm. Science, 287: 303-305, http:// www.goldenrice.org/PDFs/Ye_et_al_Science_2000.pdf

Zimmerman, M.B. and Hurrel, R.F. (2002). Improving iron, zinc and vitamin A nutrition through plant biotechnology. Current Opinion in Biotechnology, 13(2):142-145, https:// doi.org/10.1016/S0958-1669(02)00304-X 